\title{
Do age and time of practice predict the development of life skills among
}

youth futsal practitioners?

\section{¿La edad y el tiempo de práctica predicen el desarrollo de habilidades}

para la vida entre los jóvenes practicantes de fútbol sala?

\section{A idade e o tempo de prática predizem o desenvolvimento de habilidades para a vida entre jovens praticantes de futsal?}

\author{
Freire, G.L.M.1; Silva, A.A. ${ }^{1}$; Moraes, J.F.V.N¹.; Costa, N.L.G.1; Oliveira, D.V².; Nascimento Junior, \\ J.R.A ${ }^{1}$. \\ ${ }^{1}$ University Federal do Vale do São Francisco, Brazil $;{ }^{2}$ University State of Maringá, Brazil
}

\begin{abstract}
(150 words) (same order that title)
The practice of sports has been considered one of the main tools for the life skills development among youth sport participants. This cross-sectional study investigated the predicting role of age and time of practice in the development of life skills among 207 male youth futsal practitioners from the state of Pernambuco, Brazil. The instruments used were the Life Skills Scale for Sports and a semi-structured questionnaire. Data analysis was conducted through Multivariate Analysis of Variance, Pearson's correlation and Multiple Regression ( $\mathrm{p}<.05)$. The results showed significant difference $(\mathrm{p}<.05 ; \eta 2=.036-.142)$ in all life skills according to age group, evidencing higher scores for older adolescents. Further, more experienced adolescents showed higher scores at goal seating $(\mathrm{p}=.001, \eta 2=.074)$; problems solving $(\mathrm{p}=.013, \eta 2=.042)$, communication $(\mathrm{p}=.003, \eta 2=.054)$ and total life skills $(\mathrm{p}=.002, \eta 2=.057)$. There was significant $(\mathrm{p}<.05)$ and positive correlation between age and almost all life skills subscales. Multiple regression revealed only age presented positive prediction toward life skills. It can be concluded that age is a predictor of life skills development among youth futsal practitioners.
\end{abstract}

Keywords: Positive Youth Development; Adolescents; Sport.

RESUMEN (150 palabras) (mismo orden que títulos)

La práctica del deporte ha sido considerada una de las principales herramientas para el desarrollo de habilidades para la vida entre los jóvenes participantes en el deporte. Este estudio transversal investigó el papel predictivo de la edad y el tiempo de práctica en el desarrollo de habilidades para la vida entre 207 practicantes de futsal masculinos del estado de Pernambuco, Brasil. Los instrumentos utilizados fueron la Escala de habilidades para la vida deportiva y un cuestionario semiestructurado. El análisis de los datos se realizó a través del Análisis de varianza multivariante, la correlación de Pearson y la Regresión múltiple ( $\mathrm{p}<.05)$. Los resultados mostraron una diferencia significativa ( $\mathrm{p}$ $<.05 ; \eta 2=.036-.142$ ) en todas las habilidades para la vida según el grupo de edad, evidenciando puntuaciones más altas para los adolescentes mayores. Además, los adolescentes más experimentados mostraron puntajes más altos en la meta sentada $(\mathrm{p}=.001, \eta 2=.074)$; resolución de problemas $(\mathrm{p}=.013, \eta 2=.042)$, comunicación $(\mathrm{p}=.003, \eta 2=.054)$ y 


\section{Freire, Silva, Moraes, Costa, Oliveira, \& Nascimento Junior}

habilidades para la vida total $(\mathrm{p}=.002, \eta 2=.057)$. Hubo una correlación significativa $(\mathrm{p}<.05)$ y positiva entre la edad y casi todas las subescalas de habilidades para la vida. La regresión múltiple reveló que solo la edad presentaba predicciones positivas hacia las habilidades para la vida. Se puede concluir que la edad es un predictor del desarrollo de habilidades para la vida entre los jóvenes practicantes de fútbol sala.

Palabras clave: Desarrollo Juvenil Positivo; Adolescentes Deporte.

RESUMO (1500 palavras) (mesma ordem como títulos)

A prática esportiva tem sido considerada uma das principais ferramentas para o desenvolvimento de habilidades para a vida entre jovens praticantes de esportes. Este estudo transversal investigou o papel preditivo da idade e do tempo de prática no desenvolvimento de habilidades para a vida em 207 jovens praticantes de futsal do sexo masculino do estado de Pernambuco, Brasil. Os instrumentos utilizados foram a Escala de Habilidades para a Vida Esportiva e um questionário semiestruturado. A análise dos dados foi realizada por meio da Análise Multivariada de Variância, correlação de Pearson e Regressão Múltipla $(\mathrm{p}<0,05)$. Os resultados mostraram diferença significativa $(\mathrm{p}<0,05$; $\eta 2=0,036-0,142$ ) em todas as habilidades para a vida de acordo com a faixa etária, evidenciando escores mais altos nos adolescentes mais velhos. Além disso, os adolescentes mais experientes apresentaram pontuações mais altas nos assentos para as metas $(p=0,001 ; \eta 2=0,074)$; resolução de problemas $(p=0,013, \eta 2=0,042)$, comunicação $(p=0,003$, $\eta=0,054)$ e habilidades totais para a vida $(p=0,002, \eta 2=0,057)$. Houve correlação significativa $(p<0,05)$ e positiva entre idade e quase todas as subescalas de habilidades para a vida. A regressão múltipla revelou que apenas a idade apresentou predição positiva em relação às habilidades para a vida. Pode-se concluir que a idade é um preditor do desenvolvimento de habilidades para a vida entre jovens praticantes de futsal.

Palavras chave: Desenvolvimento Positivo de Jovens; Adolescentes; Esporte.

\section{INTRODUCTION}

In recent years, positive interventions in favor of the development of young people have sought to address the determinants of health risk behaviors of adolescents, with sports being one of the areas that contribute to the positive young development (PYD) (Johnston et al., 2013; Pierce, Gould, \& Camiré. 2017; Cronin et al., 2018; Camiré et al., 2019; Cronin et al., 2019). PYD's approach postulates that all young people have the potential for positive, successful and healthy development throughout adolescence (Lerner et al., 2005; Lerner et al., 2017). This perspective opposes a traditional prevalence that considers adolescence a sensitive period for PYD due to increased opportunities that can lead to the adoption of risk behaviors (e.g. sexual behavior, drug use, alcoholic beverages) (Connell, Gilreath, \& Hansen, 2009; Gunning et al., 2010). PYD in organized sports can be a tool of paramount importance for PYD (Bruner et al., 2017; Lerner et al., 2017; Vierimaa, Erickson, Côté, \& Gilbert, 2012). As a result, PYD approaches have gained popularity among researchers over the past decade, conducting researches into the proliferation of PYD in sporting contexts (Bruner et al., 2017; Vierimaa et al., 2012).
In this context, sports practice can favor the positive development of the physical, social, emotional and moral aspects of adolescents (Camiré, Trudel, \& Forneris, 2012; Pierce, Gould, \& Camiré, 2017). On the other hand, negative experiences can result in physical, psychological and professional problems, which can persist in adulthood and entail significant personal, social and economic costs (Ciocanel, Power, Eriksen, \& Gillings, 2017). Among the main negative experiences that sports provides, we highlight the frustrations with performance, lack of pleasure, pressure for results, bullying and injuries (Myer et al., 2015; Temple \& Crane, 2016), which can lead to the abandonment of sports practice, in addition to being associated with the adoption of risk behaviors (Connell et al., 2009; Gunning et al., 2010). Bruner et al. (2017) and Vierimaa et al. (2012) show that positive interventions from sports practice can prevent risk behaviour (eg. drug use, alcohol) and increase the personal growth of young people.

Studies have pointed out that sports practice is one of the main tools for PYD and, consequently, the development of life skills, which are defined as the skills needed to cope with the demand of day-to-day requirements (Hodge \& Danish, 1999). Recent studies highlight that sports practice favors the development 


\section{Age, time of practice and development of life skills in young futsal players}

of various skills for life, such as leadership, problem solving, teamwork, social skills, emotional skills, time control and communication (Camiré, Rathwell, Turgeon $^{3}$, \& Kendellen, 2019; Lorcan D Cronin \& Allen, 2018; Johnston, Harwood, \& Minniti, 2013; Mossman \& Cronin, 2019; Pierce et al., 2017).

One of the sports modalities that most attracts practitioners in Brazil is futsal, this high adhesion of young people to this sport may be associated with the fact that futsal resembles football (soccer), one of the most practiced sports in the world (Daolio, 1997; Reis, 2014). Thus, the practice of this modality in childhood and adolescence increases the probability of psychosocial development of young people and taking pleasure in its practice are key aspects for a good experience in the modality (Reis, 2014). On the other hand, the difficulty in reconciling sport and school and the problems with the coaches are the main factors that lead adolescents to abandon futsal (Hallal, Nascimento, Hackbart, \& Rombaldi, 2008).

Although the literature presents consistent evidence regarding the role of sports practice in the development of skills for life (Camiré et al., 2019; Camiré et al., 2012; L. Cronin et al., 2019; Cronin \& Allen, 2018; Pierce et al., 2017), there are several factors that can interfere with PYD through sport (Myer et al., 2015; Temple \& Crane, 2016), for example, school performance, problems with the coach, risk behaviors, conflicts with parents, age and practice time (Harwood, 2008).

Freire et al. (2020) conducted a study with adolescents' practitioners of individual sports and verified that time of practice was positively associated with the development of life skills in adolescents. However, the association of age and time of practice with the life skills development was not explored among team sports participants', being the gap that the present study aims to explore. Therefore, this study is relevant to the extent that increase knowledge about the topic, and help guiding the work of physical education professionals, coaches, parents, and sport psychologists that are involved in the development of youth sports practitioners. Thereby making it possible to use the results as the parameters for creating strategies for the empowerment of the PYD, and, as a consequence, the development of the life skills.

In this scenario, the aim of this study was to investigate the predicting role of age and time of practice in perception of life skills development among Brazilian youth futsal practitioners. The initial hypothesis is that both age and time of practice will emerge as positive predictors of the life skills development. Further, older and more experienced practitioners will show higher score of life skills development.

\section{METHODS}

\section{Study Desing}

This is a descriptive study with transversal delineation and methodological research (Ato, López \& Benavente, 2013). The study was developed through the guidelines of the Strengthening the Reporting of Observational Studies in Epidemiology (STROBE) (Malta, Cardoso, Bastos \& Magnani, 2010). Participants

This cross-sectional study included 207 male practitioners of futsal, aged between 12 and 17 years, who participated of regional competitions in the state of Pernambuco, Brazil. The participants showed mean age of $14.47 \pm 1.65$ years and practice of time of 6.92 \pm 3.04 years. Participants were selected in a nonprobabilistic way and by convenience. The inclusion criteria were as follows: 1) to practice the sport for at least one year; and 2) having been part of the team for at least three months. Only the participants who had the consent term signed by the coaches (responsible for the adolescents in the events) were selected to the research.

\section{Instruments}

Life skills development. The 43-item Life Skills Scale for Sport (Lorcan Donal Cronin \& Allen, 2017) and validated for Portuguese-speaking sport participants (Nascimento-Junior et al., 2019) was used to measure how futsal practitioners perceived life skills development. This 43-item scale uses the stem "This sport has taught me to. .." which is followed by items assessing: teamwork (7 items; "work well within a team/group"), goal setting ( 7 items; "set challenging goals"), time management (4items; "manage my time well"), emotional skills (4 items; "use my emotions to stay focused"), interpersonal communication (4 items; "speak clearly to others"), social skills (5 items; "get involved in group activities"), leadership (8 items; "organize team/group members to work together"), and problem solving and decision making (4 items; "think carefully about a problem"). In the end, the total 


\section{Freire, Silva, Moraes, Costa, Oliveira, \& Nascimento Junior}

score of skills for life it was also calculated, making an average of all items. Participants responded all items according to the following scale: 1 (not at all), 2 (a little), 3 (some), 4 (a lot), and 5 (very much). The alpha values for the eight subscales and total scale were as follows: teamwork $=.70$; goal setting $=.80$; social skills $=.76$; problem solving $=.76$; time management $=.76$; emotional skills $=.76$; leadership $=.81 ;$ communication $=.73$; and total like skills $=.94$, indicating strong reliability (Hair, Risher, Sarstedt, \& Ringle, 2019).

\section{Age range and practice time}

The age group and time of practice were analyzed by means of a semi-structured questionnaire prepared by the authors, in which the participant should indicate the answer in years and / or months. For the comparison of the life skills according to these variables, the participants were divided into three groups according to the "Median Split" process, as shown in the classification below:

- $\quad$ Age range: $12-13$ years $(\mathrm{n}=72), 14-15$ years $(n=65)$, and $16-17$ years $(n=70)$;

- Practice time: $1-5$ years $(n=65), 6-8$ years $(n=73)$, and $9-12$ years $(n=69)$.

\section{Procedures}

Initially, authorization was requested to carry out the research with the organizing committee and the coaches responsible for the teams. Afterwards, the study was approved by the Ethics Committee in Human Research under the opinion ( $\mathrm{n}^{\circ}$ 2.700.718). For the collection of data, the coaches and, subsequently, the athletes of the participating teams were contacted. The data collection took place at the site of the competition, after the signature of the free and informed consent term, and had a duration of approximately 20 minutes. Data collection was conducted by the authors of the study. The order of the questionnaires was randomized among the participants and the researchers performed the application individually.

\section{Data Analysis}

Preliminary data analyses, descriptive statistics, correlations, and standard multiple regression were conducted using SPSS version 23 (IBM Corporation, 2015). All major assumptions of the statistical tests conducted were met. Multivariate Analysis of Variance (MANOVA) was used to compare the life skills subscales and total life skills score according to age group and time of practice. The magnitude of the differences between the groups was analyzed through the eta partial squared, which shows a typical measure of deviation between group means, allowing for real quantification of the difference between them. Cohen (1977) described size effect as small $(\eta 2=.01)$, medium $(\eta 2=.06)$ or large $(\eta 2=.13)$. Spearman's correlation was used to investigate the relationship of age and time of practice with the life skills subscales among youth futsal practitioners. A multiple regression analysis was used to determine whether age and time of practice predict the dimensions of life skills. Several models (nine) were conducted using the enter method to insert the variables in order to investigate the prediction of age and time of practice (independent variables) on life skills subscales (teamwork, goal setting, social skills, emotional skills, problem solution, leadership, time control, communication and total life skills) (dependent variables). All independent variables were included together in the model in the same block. There were no sufficiently strong correlations between variables that indicated problems with multicollinearity. In addition, a post hoc statistical power analysis in G*Power 3.1.9 (Faul, Erdfelder, Lang, \& Buchner, 2007) revealed our statistical power to be $99.9 \%$ based on our sample of 207 participants, a medium effect size (.15) according to Cohen (1992) f2 criteria, and a $.05 \mathrm{p}$ value.

\section{RESULTS}

The results presented in Table 1 show that the values reported on the perception of the life skills development ranged from 1.25 to 5 , and the values of the skewness and kurtosis ranged between -.35 and .60 , respectively. The mean scores on the 1-5 response scale of the LSSS revealed that players perceived they were developing their life skills through sports. The mean scores from highest to lowest were as follows: Teamwork $(\mathrm{M}=4.08$, $\mathrm{SD}=.61)$, Communication $(\mathrm{M}=4.02, \mathrm{SD}=.75)$, goal setting $(\mathrm{M}=4.01, \mathrm{SD}=.68)$, leadership $(\mathrm{M}=3.91$, $\mathrm{SD}=.91)$, social skill $(\mathrm{M}=3.87, .72)$, problem solving $(\mathrm{M}=3.86, \quad \mathrm{SD}=.78)$, emotional skill $(\mathrm{M}=3.82$, 


\section{Age, time of practice and development of life skills in young futsal players}

$\mathrm{SD}=.83)$, time management $(\mathrm{M}=3.69, \mathrm{SD}=.79)$. Based on these scores and the total life skills score (M $=3.91, \mathrm{SD}=.55$ ).

Table 1. Descriptive values (minimum, maximum, mean, standard deviation, skewness and kurtosis) of the variables.

\begin{tabular}{|c|c|c|c|c|}
\hline Variables & Min. Max & M (SD) & Sk & $\mathbf{K}$ \\
\hline Teamwork & $\begin{array}{ll}1.86 & 5.00\end{array}$ & $4.08(.61)$ & -.58 & .32 \\
\hline & 5.00 & 4.0 & -.58 & .28 \\
\hline & 5.00 & & -.35 & -.17 \\
\hline olving ${ }^{a}$ & 1.25 & & -.55 & .31 \\
\hline kills & 1.25 & 3.8 & -.38 & -.50 \\
\hline & 1.88 & 3.9 & -.36 & .32 \\
\hline & 1.25 & 3.6 & -.28 & -.33 \\
\hline Comm & 1.75 & $4.02(.75)$ & -.59 & -.34 \\
\hline Total Life Skills & 1.98 & $3.91(.55)$ & -.57 & .60 \\
\hline
\end{tabular}

Note: $\mathrm{M}=$ Mean; $\mathrm{Sd}=$ Standard deviation; $\mathrm{Sk}=$ Skewness; $\mathrm{Ku}=$ Kurtosis; a) problem solving and decision making; b) interpersonal communication skills;
When comparing the dimensions of life skills of the Brazilian youth futsal practitioners according to age (Table 2), there was significant difference between groups in all dimensions $(\mathrm{p}<0.05)$. It is highlighted that older practitioners presented higher scores in all dimensions and in the total score of life skills when compared to younger practitioners. This effect can be considered large $(\eta 2>.13)$.

When comparing the life skills subscales of the Brazilian youth futsal practitioners according to the time of practice (Table 3), there was significant difference between groups in problem solving $(p=.013)$, communication $(p=.003)$ and total score of life skills $(\mathrm{p}=.002)$. As shown in Table 3, more experienced adolescents presented higher scores at these dimensions and in the total score of life skills when compared to less experienced adolescents. This effect can be considered large ( $\eta 2>.13)$.

Table 4 shows the following significant correlations $(\mathrm{p}<.01$; and $\mathrm{p}<.05)$ between the variables: age with practice time ( $\mathrm{r}=.34)$, teamwork $(\mathrm{r}=.25)$, goal setting $(\mathrm{r}=.30)$, social skills $(\mathrm{r}=.20)$, problem solving $(\mathrm{r}=.26)$, emotional skills $(\mathrm{r}=.16)$, leadership $(\mathrm{r}=.31)$, time control $(\mathrm{r}=.19)$, communication $(\mathrm{r}=.32)$ and total life skills $(\mathrm{r}=.35)$; practice time with leadership $(\mathrm{r}=.17)$, communication $(\mathrm{r}=.18)$ and total life skills $(\mathrm{r}=.14)$.

Table 2. Comparison of life skills dimensions of Brazilian youth futsal practitioners according to age group.

\begin{tabular}{|c|c|c|c|c|c|}
\hline \multirow{3}{*}{ Variables } & \multicolumn{3}{|c|}{ Age Group } & \multirow{3}{*}{$\mathbf{p}$} & \multirow{3}{*}{$\eta 2$} \\
\hline & $12-13(n=72)$ & $14-15(n=65)$ & $16-17(n=70)$ & & \\
\hline & $\mathrm{M}(\mathrm{SD})$ & $\mathrm{M}(\mathrm{SD})$ & $\mathrm{M}(\mathrm{SD})$ & & \\
\hline Teamwork & $3.88(.66)^{\mathrm{c}}$ & $4.08(.57)$ & $4.29(.53)$ & $<.001 *$ & .075 \\
\hline Goal Setting & $3.76(.77)^{\mathrm{c}}$ & $3.91(.58)$ & $4.36(.50)$ & $<.001 *$ & .140 \\
\hline Social Skills & $3.70(.76)^{\mathrm{c}}$ & $3.89(.64)$ & $4.03(.73)$ & $.024 *$ & .036 \\
\hline Problem Solving ${ }^{\mathrm{a}}$ & $3.59(.84)^{\mathrm{c}}$ & $3.88(.79)$ & $4.14(.61)$ & $<.001 *$ & .084 \\
\hline Emotional Skills & $3.65(.86)^{\mathrm{c}}$ & $3.75(.83)$ & $4.05(.74)$ & $.013^{*}$ & .041 \\
\hline Leadership & $3.75(1.12)^{\mathrm{c}}$ & $3.71(.72)$ & $4.24(.71)$ & $.001 *$ & .071 \\
\hline Time management & $3.52(.83)^{\mathrm{c}}$ & $3.58(.78)$ & $3.90(.73)$ & $.011 *$ & .044 \\
\hline Communication $^{\mathrm{b}}$ & $3.78(.77)^{\mathrm{c}}$ & $3.91(.69)$ & $4.36(.66)$ & $<.001 *$ & .112 \\
\hline Total Life Skills & $3.70(.61)^{\mathrm{c}}$ & $3.85(.51)$ & $4.19(.41)$ & $<.001 *$ & .142 \\
\hline
\end{tabular}

*Significant difference - $\mathrm{p}<.05$ - MANOVA. Note: $\mathrm{M}=\mathrm{Mean} ; \mathrm{Sd}=$ Standard deviation; ${ }^{\mathrm{a}}$ problem

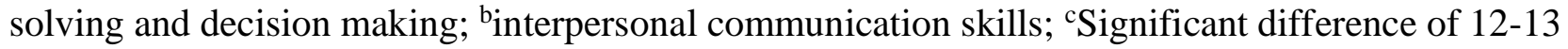
years with 16-17 years. 
Table 3. Comparison of life skills dimensions of Brazilian youth futsal practitioners according to practice time.

\begin{tabular}{|c|c|c|c|c|c|}
\hline \multirow{3}{*}{ Variables } & \multicolumn{3}{|c|}{ Time of Practice } & \multirow{3}{*}{$\mathbf{p}$} & \multirow{3}{*}{$\eta 2$} \\
\hline & $1-5$ years $(n=65)$ & $6-8$ years $(n=73)$ & $9-12$ years $(n=69)$ & & \\
\hline & $\mathrm{M}(\mathrm{SD})$ & $\mathrm{M}(\mathrm{SD})$ & $\mathrm{M}(\mathrm{SD})$ & & \\
\hline Teamwork & $4.09(.58)$ & $3.96(64)$ & $4.20(.60)$ & .070 & .026 \\
\hline Goal Setting & $4.07(.66)$ & $3.77(.71)^{\mathrm{c}}$ & $4.21(.59)$ & $<.001 *$ & .074 \\
\hline Social Skills & $3.80(.78)$ & $3.80(68)$ & $4.01(.69)$ & .167 & .017 \\
\hline Problem Solving ${ }^{\mathrm{a}}$ & $3.91(.74)$ & $3.66(.85)^{\mathrm{d}}$ & $4.04(.71)$ & $.013 *$ & .042 \\
\hline Emotional Skills & $3.89(.80)$ & $3.68(.89)$ & $3.90(.78)$ & .210 & .015 \\
\hline Leadership & $3.79(.72)$ & $3.84(1.15)$ & $4.09(.75)$ & .118 & .021 \\
\hline Time management & $3.64(.86)$ & $3.52(.82)$ & $3.84(.67)$ & .054 & .028 \\
\hline Communication $^{\mathrm{b}}$ & $3.92(.77)$ & $3.87(.79)^{\mathrm{c}}$ & $4.26(.63)$ & $.003 *$ & .054 \\
\hline Total Life Skills & $3.90(.54)$ & $3.76(.59)^{\mathrm{d}}$ & $3.91(.55)$ & $.002 *$ & .057 \\
\hline
\end{tabular}

* Significant difference $-\mathrm{p}<.05$. MANOVA. Note: $\mathrm{M}=$ Mean; $\mathrm{Sd}=$ Standard deviation; ${ }^{\mathrm{a}}$ problem solving and decision making; binterpersonal communication skills; ' ${ }^{2}$ Significant difference $(\mathrm{p}<.05)$ of 6-8 years with 1-5 years and 9-12 years; ${ }^{\mathrm{d} S i g n i f i c a n t}$ difference $(\mathrm{p}<.05)$ of $6-8$ years with $9-12$ years.

Table 4. Correlation between the dimensions of life skills, time of practice and the age among Brazilian youth futsal practitioners.

\begin{tabular}{|c|c|c|c|c|c|c|c|c|c|c|c|}
\hline Variables & 1 & 2 & 3 & 4 & 5 & 6 & 7 & 8 & 9 & 10 & 11 \\
\hline 1.Age & & $.34 * *$ & $.25 * *$ & $.30 * *$ & $.20 *$ & $.26 * *$ & $.16^{*}$ & $.31 * *$ & $.19 * *$ & $.32 * *$ & $.35 * *$ \\
\hline 2. Time of Practice & & & .09 & .11 & .11 & .07 & -.02 & $.17 *$ & .12 & $.18 *$ & $.14 *$ \\
\hline 3.Teamwork & & & & $.66 * *$ & $.52 * *$ & $.55^{* *}$ & $.33 * *$ & $.66^{* * *}$ & $.28 * *$ & $.50 * *$ & $.79 * *$ \\
\hline 4.Goal Setting & & & & & $.46^{* *}$ & $.52 * *$ & $.48 * *$ & $.60 * *$ & $.41 * *$ & $.49 * *$ & $.78 * *$ \\
\hline 5.Social Skills & & & & & & $.52 * *$ & $.28 * *$ & $.48 * *$ & $.33 * *$ & $.55^{* *}$ & $.69 * *$ \\
\hline 6.Problem Solving ${ }^{\mathrm{a}}$ & & & & & & & $.42 * *$ & $.53 * *$ & $.30 * *$ & $.46 * *$ & $.71 * *$ \\
\hline 7.Emotional Skills & & & & & & & & $.39 * *$ & $.42 * *$ & $.34 * *$ & $.58 * *$ \\
\hline 8.Leadership & & & & & & & & & $.44 * *$ & $.70 * *$ & $.85^{* *}$ \\
\hline 9.Time management & & & & & & & & & & $.53 * *$ & $.60 * *$ \\
\hline 10.Communication ${ }^{\mathrm{a}}$ & & & & & & & & & & & $.77 * *$ \\
\hline 1 Total Life Skills & & & & & & & & & & & \\
\hline
\end{tabular}

Significant correlation: $* * \mathrm{p}<.01 ; * \mathrm{p}<.05$. Spearman correlation. Note: ${ }^{\mathrm{a}}$ problem solving and decision making, binterpersonal communication skills.

Standard multiple regression analyses (see Table 5) revealed that our model which included age and time of practice explained a significant amount of the variance life skills subscales and total life skills (R2 range .03 to. $13, \mathrm{p}<.05)$. However, only age made the largest positive contribution to teamwork $(\beta=.10, p$
$<.001)$, goal setting $(\beta=.14, \mathrm{p}<.001)$, social skills $(\beta$ $=.10, \mathrm{p}<.01)$, problem solving $(\beta=.14, \mathrm{p}<.001)$, emotional skills $(\beta=.11, \mathrm{p}<.01)$, leadership $(\beta=.12$, $\mathrm{p}<.01)$, time management $(\beta=.08, \mathrm{p}<.05)$, interpersonal communication skills $(\beta=.13, \mathrm{p}<.001)$ and total life skills $(\beta=.12 ; \mathrm{p}<.001)$. 
Table 5. Age and time of practice as predictors of life skills development of Brazilian youth futsal practitioners.

\begin{tabular}{|c|c|c|c|c|c|c|c|c|c|}
\hline \multirow[t]{2}{*}{ Predictors } & Teamwork & Goal Setting & $\begin{array}{l}\text { Social } \\
\text { Skills }\end{array}$ & $\begin{array}{l}\text { Problem } \\
\text { Solving }\end{array}$ & $\begin{array}{c}\text { Emotional } \\
\text { Skills }\end{array}$ & Leadership & $\begin{array}{c}\text { Time } \\
\text { management }\end{array}$ & Com. $^{\text {b }}$ & $\begin{array}{c}\text { Total } \\
\text { Life Skills }\end{array}$ \\
\hline & $\beta(\mathrm{CI})$ & $\beta(\mathrm{CI})$ & $\beta(\mathrm{CI})$ & $\beta(\mathrm{CI})$ & $\beta(\mathrm{CI})$ & $\beta(\mathrm{CI})$ & $\beta(\mathrm{CI})$ & & \\
\hline \multirow[t]{2}{*}{ Age } & .10 & .14 & .10 & .14 & .11 & .12 & .08 & .13 & .12 \\
\hline & $(.04, .15)^{* * * *}$ & $.08, .20) * * *$ & $(.02, .15)^{* * *}$ & $(.07, .20) * * *$ & $(.03, .18)^{* * *}$ & $(.04, .20)^{* * *}$ & $(.01, .15) *$ & $(.06, .19) * * * *$ & $(.07, .16) * * *$ \\
\hline TP & $\begin{array}{c}-.01 \\
(-.03, .02)\end{array}$ & $\begin{array}{c}.01 \\
(-.03, .03)\end{array}$ & $\begin{array}{c}.01 \\
(-.02, .04)\end{array}$ & $\begin{array}{c}-.01 \\
(-.04, .03)\end{array}$ & $\begin{array}{c}-.02 \\
(-.06, .01)\end{array}$ & $\begin{array}{c}.02 \\
(-.03, .05)\end{array}$ & $\begin{array}{c}.02 \\
(-.02, .05)\end{array}$ & $\begin{array}{c}.02 \\
(-.01, .05)\end{array}$ & $\begin{array}{c}.01 \\
(-.02, .03)\end{array}$ \\
\hline$R^{2}$ & .06 & .11 & .04 & .08 & .03 & .05 & .03 & .10 & .13 \\
\hline$F$ & $6.392 * *$ & $13.146^{* * *}$ & $4.773^{* *}$ & $8.768 * * *$ & $4.256^{*}$ & $5.863^{* *}$ & $4.138 *$ & $11.575^{* * *}$ & $15.156^{* * *}$ \\
\hline VIF & 1.139 & 1.139 & 1.139 & 1.139 & 1.139 & 1.139 & 1.139 & 1.139 & 1.139 \\
\hline DW & 1.796 & 1.807 & 1.847 & 1.927 & 1.840 & 2.169 & 2.152 & 1.879 & 1.742 \\
\hline
\end{tabular}

Note. Only the unstandardized regression coefficients which were less than our significance level of .05 are highlighted in bold. $\mathrm{TP}=$ Time of practice; $\beta=$ Standardized regression coefficient $\mathrm{CI}=95 \%$ confidence interval; VIF = Variance Inflation Factors; DW = Durbin-Watson; ${ }^{a}$ problem solving and decision making, binterpersonal communication skills. ${ }^{*} p<.05, * * p<.01, * * * p<.001$.

\section{DISCUSSION}

This research aimed to investigate the predicting role of age and time of practice in the development of life skills among youth Brazilian futsal practitioners. The main results revealed that only age proved to be a predictor for the life skills development (see Table 5). In addition, older adolescents presented higher scores in all dimensions of life skills (see Table 2), whereas more experienced practitioners presented higher scores in some dimensions of life skills (see Table 3 ).

The main finding of this study refers to the predicting role of age in the perception of futsal practitioners regarding the life skills development (Tables 4 and 5). It is worth noticing that the biological maturation of the adolescent is a factor that helps in the development of several life skills (Pierce et al., 2017). Further, it is worth pointing out that all the dimensions of life skills predicted by age refer to the PYD theory (Lerner et al., 2017). It explains the fact that perception of life skills development is increased when the practitioner manages to put the sports demands into practice during day-to-day demands, such as training routines school, housework. Thus, as age progresses, the perception of the development of these life skills tend to increase.

On the other hand, it was observed that time of practice within futsal did not prove to be a predictor factor for the life skills development (Tables 4 and 5), indicating that the practice of the sport alone does not lead to the development of such skills (Camiré et al., 2019; Cronin et al., 2019; Cronin \& Allen, 2018). Although several studies point to the role of sports practice for PYD (Camiré et al., 2019; Lorcan D Cronin \& Allen, 2018; Johnston et al., 2013; Mossman \& Cronin, 2019; Pierce et al., 2017), it is important to note that the sport only is highly predictor of PYD when the experiences by adolescents within sports practice are positive (Bruner et al., 2017; Vierimaa et al., 2012). In other words, sports experiences should be permeated by a pleasant climate, pleasure in practice and good interpersonal relationships with coaches/ teachers and colleagues (Camiré et al., 2019; Cronin \& Allen, 2018).

Positive experiences during sports practice favor the development of personal, social and cognitive skills, leadership, empathy, companionship, creativity and intelligence (Bruner et al., 2017; MacDonald, Côté, Eys, \& Deakin, 2012; Vierimaa et al., 2012). Other positive skills are goal setting and problem solving, which were the dimensions of life skills that were explained with higher magnitude by age and with no prediction by time of practice (Tables 4 and 5). This finding reveals that biological maturation seems to be essential to the establishment of challenging goals, plans for the future, and initiative, which include effort-related elements, attention and improvement of physical skills (do Nascimento Júnior et al., 2018; Sullivan, LaForge-MacKenzie, \& Marini, 2015).

The absence of association of time of practice time with the life skills development in this study may be

Correspondence to: Gabriel Lucas, Morais Freire. Dirección Postal: Universidade Federal do Vale do São Francisco (Univasf) - Petrolina (PE), Brasil. Email: bi88el@gmail.com 


\section{Freire, Silva, Moraes, Costa, Oliveira, \& Nascimento Junior}

related to the perception of youth sport participants about experiences during practice. It is known that the negative experiences during sports can not only harm the performance of the practitioner and the athlete, but also the PYD (Connell et al., 2009; Gunning et al., 2010). Among the factors that lead to negative experiences, we highlight excessive training, interpersonal conflicts, bullying, injury and low perception of competence (Myer et al., 2015; Temple $\&$ Crane, 2016).

Another hypothesis presented was that the older adolescents would have higher perception of life skills development within futsal practice. The findings confirm this hypothesis (Table 2), demonstrating that age seems to be an indicator for the development of life skills through the practice of futsal. Similar results have been found by Nascimento Junior et al. (2018) in a study with adolescents' practitioners of team sports. The authors noted that the younger practitioners demonstrated higher negative experience with the sport when compared to older practitioners. On the contrary, in a recent meta-analysis, Ciocanel et al. (2016) showed that positive interventions in favor of PYD through sport have a significant effect on academic demands, as well as with life skills. The authors still claimed that age did not present itself as an intervention factor in the PYD. It should be noted that age is not the only inherent factor for the life skills development within sport. The quality of the program that young people are inserted into and parental support are considered factors inherent in the life skills development (Ciocanel et al., 2017; Mossman \& Cronin, 2019).

Hansen and Larson (2007) claimed that differences in levels of physical, psychological and social skills can be explained through the time of practice within a sport program. Contrary to these findings and to the hypotheses presented in this investigation, the results point out that the time of practice was not an intervention factor in the development of skills for life through the practice of futsal (Table 5). This finding indicates that time of practice does not seem to interfere with the perception of life skills development among adolescents, demonstrating the need for further clarification on the direction of the perception of life skills as a function of the time of practice in youth sports participants. Studies point out that the quality of sporting experiences at a later stage is influenced by the choices of young people in the sports arena (Camiré et al., 2019; Holt et al., 2017). While some youth people demonstrate a greater commitment to the development of specific skills through sport practice (e.g. life skills), other adolescents may dedicate most of their time to other activities (Cronin et al., 2018; Cronin et al., 2019). Considering that adolescence is a critical phase of development, some adolescents may use sports experiences to improve their academic standards, in homework, in the sport itself, while others may not even transfer such experiences to other contexts of life (Côté \& Erickson, 2015; Coté, Horton, MacDonald, \& Wilkes, 2009; Côté, Turnnidge, \& Evans, 2014).

Additionally, analyzing the differences at life skills development of the adolescents according to time of practice (see Table 3), it was observed that more experienced practitioners reported higher scores at problems solving and decision making and at total score of life skills when compared to less experienced adolescents. Thus, these skills seem to be enhanced with the increase of the time of practice. Similar results were found by Freire et al. (2020), who showed that time of practice is positively associated with the life skills development among youth individual sports practitioners. In this perspective, the findings of the present study corroborate those found in the literature, demonstrating that time of practice can be a percussive in the development of life skills among sports practitioners (Camiré et al., 2019; Holt et al., 2017).

Nevertheless, it was observed that adolescents less experienced reported higher scores at goal seating and interpersonal communication skills when compared to adolescents with moderate experiences (6-8 years). It is noteworthy that these skills help young people to express their desires, feelings and attitudes in an appropriate way inside and outside the sports context. Pierce et al. (2019) affirm that PYD, as well as life skills development, is a complex process because adolescence is considered a sensitive period for PYD due to the increased opportunities that can lead to the adoption of risky behaviors (e.g. sexual behavior, drug use, alcoholic beverages) (Connell, Gilreath, \& Hansen, 2009; Gunning et al., 2010).

Based on the mean scores obtained in the subscales of life skills (Table 1), it is possible to note that the adolescents perceive themselves with high life skills development within futsal practice (see Table 1). A 


\section{Age, time of practice and development of life skills in young futsal players}

range of studies show that sports practice contributes to a range of life skills, such as the goal setting, leadership, problem solving, leadership and time management (Johnston et al., 2013; Pierce, Gould, \& Camiré. 2017; Cronin et al., 2018; Camiré et al., 2019; Cronin et al., 2019). Johnston et al. (2013) showed that many of the life skills can be developed through sports practice, such as: teamwork, goal setting, time management, emotional skills, interpersonal communication, social skills, leadership and problem solving. However, it should be noted that there are other ways that can be more or less effective in developing life skills through sports practices that have not been approached in the present study.

Despite the contributions to literature, this study has some limitations that are worth considering. First, because it is a cross-sectional and a single-instrument study (life skills), the data obtained allowed only associations between variables, but not causality inferences. Further, the number of participants did not allow some comparisons, such as performance levels, winner $\mathrm{x}$ loser, and gender, since only boys were evaluated. Furthermore, the wide range of the age group and time of practice of the participants are factors that can limit the findings of this study. However, we carried out comparative analyzes to verify whether this wide coverage interfered with the results obtained. Finally, it should be noted that other practices experienced by youth people in different contexts have not been investigated and it is known that each daily experience can influence the life skills development. Thus, future investigations should carry out longitudinal design, which could make several measurements of life skills development at different competitive levels and moments. Further, correlations with other instruments, and the conduction of multilevel analysis should help to understand the relationships between these variables in different groups and moments.

\section{CONCLUSIONS}

It can be concluded that only age can be considered as a positive predictor of the life skills development among Brazilian youth futsal practitioners, while the time of practice of the modality did not seem to be an intervention factor for the life skills development of the adolescents investigated. It should be noted that older adolescents presented higher perception of the life skills development. From a practical standpoint, the importance of sports programs based on the development of life skills by coaches, physical education professionals and sports psychologists stands out in order to optimize the positive youth development.

\section{REFERENCES}

1. Ato, Manuel; López, Juan J.; Benavente, Ana (2013). Un sistema de clasificación de los diseños de investigación en psicología. Anales de Psicología, 29 (3), 1038-1059.

2. Bruner, M. W., Balish, S. M., Forrest, C., Brown, S., Webber, K., Gray, E., ... Shields, C. A. (2017). Ties that bond: youth sport as a vehicle for social identity and positive youth development. Research quarterly for exercise and sport, 88(2), 209-214.

/doi.org/10.1080/02701367.2017.1296100

3. Camiré, M., Rathwell, S., Turgeon ${ }^{3}$, S., \& Kendellen, K. (2019). Coach-athlete relationships, basic psychological needs satisfaction and thwarting, and the teaching of life skills in Canadian high school sport. International journal of sports science \& coaching, 17(4) 54-79. doi.org/10.1177/1747954119869542

4. Camiré, M., Trudel, P., \& Forneris, T. (2012). Coaching and transferring life skills: Philosophies and strategies used by model high school coaches. The Sport Psychologist, 26(2), 243-260. doi.org/10.1123/tsp.26.2.243

5. Ciocanel, O., Power, K., Eriksen, A., \& Gillings, K. (2017). Effectiveness of positive youth development interventions: A metaanalysis of randomized controlled trials. Journal of youth and adolescence, 46(3), 483504.

doi.org/10.1007/s10964-016-0555-6

6. Cohen, J. (1992). A power primer. Psychological bulletin, 112(1), 155. doi.org/10.1037/0033-2909.112.1.155

7. Connell, C. M., Gilreath, T. D., \& Hansen, N. B. (2009). A multiprocess latent class analysis of the co-occurrence of substance use and sexual risk behavior among adolescents. Journal of studies on alcohol and drugs, 70(6), 943-951.

doi.org/10.15288/jsad.2009.70.943 


\section{Freire, Silva, Moraes, Costa, Oliveira, \& Nascimento Junior}

8. Côté, J., \& Erickson, K. (2015). Diversification and deliberate play during the sampling years Routledge handbook of sport expertise (pp. 331-342): Routledge.

9. Coté, J., Horton, S., MacDonald, D., \& Wilkes, S. (2009). The benefits of sampling sports during childhood. Physical \& Health Education Journal, 74(4), 6-16.

10. Côté, J., Turnnidge, J., \& Evans, M. B. (2014). The dynamic process of development through sport. Kinesiologia Slovenica, 20(3).

11. Cronin, L., Marchant, D., Allen, J., Mulvenna, C., Cullen, D., Williams, G., \& Ellison, P. (2019). Students' perceptions of autonomysupportive versus controlling teaching and basic need satisfaction versus frustration in relation to life skills development in PE. Psychology of Sport and Exercise, 44, 79-89.

12. Cronin, L. D., \& Allen, J. (2017). Development and initial validation of the Life Skills Scale for Sport. Psychology of Sport and Exercise, 28, 105-119. doi.org/10.1016/j.psychsport.2019.05.003

13. Cronin, L. D., \& Allen, J. (2018). Examining the relationships among the coaching climate, life skills development and well-being in sport. International journal of sports science \& coaching, 13(6), 815-827. doi.org/10.1177/1747954118787949

14. Daolio, J. (1997). Cultura: educação física futebol: Editora da UNICAMP Campinas^ ${ }^{\wedge}$ eSP SP.

15. Freire, G.L.M., Neto, A.C.d.S., Cruz, M.d.C., Tavares, J.E.T., Oliveira, D.V.d., Nascimento Junior, J. R. A.d. (2020). Development of life skills in adolescents who practice individual sports. Research, Society and Development. 9(8). 15-22.

doi.org/10.33448/rsd-v9i8.5557

16. Faul, F., Erdfelder, E., Lang, A.-G., \& Buchner, A. (2007). G* Power 3: A flexible statistical power analysis program for the social, behavioral, and biomedical sciences. Behavior research methods, 39(2), 175-191.

17. Gunning, N., Jotangia, D., Nicholson, S., Ogunbadejo, T., Reilly, N., Simmonds, N., \& Wardle, H. (2010). Smoking, drinking and drug use among young people in England in 2009. London: Information Centre for Health and Social Care.
18. Hair, J. F., Risher, J. J., Sarstedt, M., \& Ringle, C. M. (2019). When to use and how to report the results of PLS-SEM. European Business Review, 31(1), 2-24.

19. Hallal, P. C., Nascimento, R. R., Hackbart, L., \& Rombaldi, A. J. (2008). Fatores intervenientes associados ao abandono do futsal em adolescentes [Factors associated with the abandonment of futsal in adolescents]. Revista Brasileira de Ciência e Movimento. 12(3). 27-32.

20. Hansen, D. M., \& Larson, R. W. (2007). Amplifiers of developmental and negative experiences in organized activities: Dosage, motivation, lead roles, and adult-youth ratios. Journal of applied developmental psychology, 28(4), 360-374.

doi.org/10.1016/j.appdev.2007.04.006

21. Harwood, C. (2008). Developmental consulting in a professional football academy: The 5Cs coaching efficacy program. The Sport Psychologist, 22(1), 109-133. doi.org/10.1123/tsp.22.1.109

22. Hodge, K., \& Danish, S. (1999). Promoting life skills for adolescent males through sport. Handbook of counseling boys and adolescent males: A practitioner's guide, 55-71.

23. Holt. N. L., Neely. K. C., Slater. L. G., Camiré. M., Côté. J., Fraser-Thomas. J.. . . . Tamminen. K. A. (2017). A grounded theory of positive youth development through sport based on results from a qualitative metastudy. International review of sport and exercise psychology. 10(1). 1-49. doi.org/10.1080/1750984X.2016.1180704

24. Johnston, J., Harwood, C., \& Minniti, A. M. (2013). Positive youth development in swimming: Clarification and consensus of key psychosocial assets. Journal of applied sport psychology, 25(4), 392-411.

doi.org/10.1080/10413200.2012.747571

25. Lerner, R. M., Lerner, J. V., Almerigi, J. B., Theokas, C., Phelps, E., Gestsdottir, S., . . . Ma, L. (2005). Positive youth development, participation in community youth development programs, and community contributions of fifth-grade adolescents: Findings from the first wave of the 4-H study of positive youth development. The Journal of Early Adolescence, 25(1), 17-71. 


\section{Age, time of practice and development of life skills in young futsal players}

doi.org/10.1177/0272431604272461

26. Lerner, R. M., Wang, J., Hershberg, R. M., Buckingham, M. H., Harris, E. M., Tirrell, J. M., . . . Lerner, J. V. (2017). Positive youth development among minority youth: A relational developmental systems model Handbook on positive development of minority children and youth (pp. 5-17): Springer. doi.org/10.1007/978-3-319-43645-6_1

27. Malta, M., Cardoso, L. O., Bastos, F. I., Magnanini, M. M. F., \& Silva, C. M. F. P. D. (2010). STROBE initiative: guidelines on reporting observational studies. Revista de saude publica, 44, 559-565.

28. MacDonald, D. J., Côté, J., Eys, M., \& Deakin, J. (2012). Psychometric properties of the youth experience survey with young athletes. Psychology of Sport and Exercise, 13(3), 332-340.

doi.org/10.1016/j.psychsport.2011.09.001

29. Mossman, G. J., \& Cronin, L. D. (2019). Life skills development and enjoyment in youth soccer: The importance of parental behaviours. Journal of sports sciences, 37(8), 850-856.

doi.org/10.1080/02640414.2018.1530580

30. Myer, G. D., Jayanthi, N., Difiori, J. P., Faigenbaum, A. D., Kiefer, A. W., Logerstedt, D., \& Micheli, L. J. (2015). Sport specialization, part I: does early sports specialization increase negative outcomes and reduce the opportunity for success in young athletes? Sports Health, 7(5), 437-442. doi.org/10.1177/1941738115598747

31. Nascimento Júnior, J. R. A., Granja, C. T. L., dos Santos, M. M., da Costa Santos, M. d. L., Silva, G. C. B., de Melo, G. F., \& de Oliveira, D. V. (2018). Estresse pré-competitivo e experiência esportiva em adolescentes de Petrolina-PE [Pre-competitive stress and sporting experience in Petrolina-PE adolescents]. Psicologia Revista. 27. 615-631. doi.org/10.23925/2594-

3871.2018v27i3p615-631
32. Nascimento-Junior, J. R. A. d., Fortes, L. d. S., Freire, G. L. M., Oliveira, D. V. d., Fiorese, L., \& Cronin, L. D. (2019). Cross-Cultural Adaptation and Psychometric Properties of the Portuguese Version of the Life Skills Scale for Sport. Measurement in Physical Education and Exercise Science, 1-14. doi.org/10.1080/1091367X.2019.1647208

33. Pierce, S., Gould, D., \& Camiré, M. (2017). Definition and model of life skills transfer. International review of sport and exercise psychology, 10(1), 186-211. doi.org/10.1080/1750984X.2016.1199727

34. Reis, C. A. M. (2014). Analysis of determinants factors to the teenagers drop out in futsal/Analise dos fatores determinantes para o abandono de adolescentes no futsal. Revista Brasileira de Futsal e Futebol, 6(19), 45-51.

35. Sullivan, P. J., LaForge-MacKenzie, K., \& Marini, M. (2015). Confirmatory factor analysis of the youth experiences survey for sport (YES-S). Open Journal of Statistics, 5(05), 421-432.

x.doi.org/10.4236/ojs.2015.55044

36. Temple, V. A., \& Crane, J. R. (2016). A systematic review of drop-out from organized soccer among children and adolescents. Soccer \& Society, 17(6), 856-881. doi.org/10.1080/14660970.2015.1100901

37. Vierimaa, M., Erickson, K., Côté, J., \& Gilbert, W. (2012). Positive youth development: A measurement framework for sport. International journal of sports science \& coaching, 7(3), 601-614. doi.org/10.1260/1747-9541.7.3.601 